\title{
Legionella shakespearei sp. nov., Isolated From Cooling Tower Water
}

\author{
USHA K. VERMA, ${ }^{1} \dagger$ DON J. BRENNER,${ }^{2}$ W. LANIER THACKER,${ }^{2}$ ROBERT F. BENSON, ${ }^{2}$ \\ GRAHAM VESEY ${ }^{3} \ddagger$ JOHN B. KURTZ, ${ }^{4}$ P. J. L. DENNIS, ${ }^{3} \ddagger$ ARNOLD G. STEIGERWALT, ${ }^{2}$ \\ JIM S. ROBINSON, ${ }^{1 *}$ AND C. WAYNE MOSS ${ }^{2}$ \\ Houseman Ltd., The Priory, Burnham, Slough SL1 7LS, United Kingdom ${ }^{1}$; Division of Bacterial and \\ Mycotic Diseases, National Center for Infectious Diseases, Centers for Disease Control, Atlanta, \\ Georgia 303332; Public Health Laboratory Service, Centre for Applied Microbiology and \\ Research, Porton Down, Salisbury, United Kingdom ${ }^{3}$; and Department of \\ Virology, John Radcliffe Hospital, Oxford OX3 9DU, United Kingdom ${ }^{4}$
}

\begin{abstract}
A Legionella-like organism (strain $214^{\mathrm{T}}$ [ $\mathrm{T}=$ type strain]) was isolated from a cooling tower in Stratford-upon-Avon, England. This strain required L-cysteine and contained cellular branched-chain fatty acids that are typical of the genus Legionella. Strain $214^{T}$ produced pink colonies on buffered charcoal-yeast extract agar. Ubiquinone Q-12 was the major quinone. Strain $214^{\mathrm{T}}$ was serologically distinct from other legionellae as determined by a slide agglutination test. The results of DNA hybridization studies showed that strain $214^{\mathrm{T}}\left(=\mathrm{ATCC} 49655^{\mathrm{T}}\right)$ is a member of a new Legionella species, Legionella shakespearei.
\end{abstract}

Members of the genus Legionella are ubiquitous inhabitants of freshwater environments $(12,18)$. These organisms flourish in natural habitats wherever water is present and also colonize engineered water systems, in particular hotand cold-water services in large buildings and recirculating cooling water systems associated with central air-conditioning plants $(11,13,23)$. The mode of transmission to humans is by inhalation of aerosols $(2,17)$ created by running water in taps or showers (9) and by sprays drifting from cooling towers and evaporative condensers $(1,10)$.

Legionellae are fastidious, require iron and cysteine, and are often found in symbiotic relationships with other microorganisms, such as protozoa, algae, cyanobacteria, and other bacteria $(22,24,25)$. Legionellae can grow on microbial organic waste products, which enables them to survive and proliferate in biofilms (8).

To date, 51 serogroups representing 32 Legionella species have been described $(3,5,20)$. Most of these organisms have been isolated from human clinical specimens from patients with pneumonia or a mild febrile disease, but some species and serogroups have not yet been implicated in causing disease. Characterization of Legionella species since the description of Legionella pneumophila has involved the use of both phenotypic methods (substrate utilization, serologic reactivity, cellular fatty acid composition, isoprenoid quinone content) and genotypic methods (restriction fragment length polymorphism analysis, DNA-DNA homology). The biochemical approach to phenotypic distinctions has at best allowed only grouping of species, although recent work has shown that phenotypic differentiation of Legionella species on the basis of substrate utilization patterns is possible (16). Because serologic reactivity, the most widely used method for species identification, may be unreliable as a means of identifying strains, genotypic methods of analysis should be

\footnotetext{
* Corresponding author.

+ Present address: BioConsultancy Services, Chalvey, Slough SL1 2TW, United Kingdom.

$\ddagger$ Present address: Thames Water Utilities, Spencer House Laboratory, Reading, Berkshire RG2 0JN, United Kingdom.
}

used if the identity of a Legionella species needs to be established (19).

In this paper we describe an isolate (strain $214^{\mathrm{T}}$ [ $\mathrm{T}=$ type strain]) of a new species that was obtained from water taken from an evaporative cooling tower. This organism is unique in that it is the first recognized pigmented Legionella species. Strain $214^{\mathrm{T}}$ forms light pink colonies when it is cultured on buffered charcoal-yeast extract (BCYE) agar. The name Legionella shakespearei is proposed for this new species.

\section{MATERIALS AND METHODS}

Isolation procedure. A 1-liter sample of water was taken from a cooling tower (Houseman Ltd. laboratory reference no. 86030153) at a site in Stratford-upon-Avon for routine testing. The sample was processed by using protocols developed by Houseman Ltd. in conjunction with the Public Health Laboratory Service. Bacteria from the 1-liter sample were concentrated on membrane filters (diameter, $142 \mathrm{~mm}$; pore size, $0.45 \mu \mathrm{m}$ ). Each filter was then aseptically comminuted with scissors and suspended in a tube containing $20 \mathrm{ml}$ of sterile distilled water. The tube was tightly capped and shaken vigorously by hand for $1 \mathrm{~min}$ to suspend the microorganisms.

A 1-ml sample of the concentrated suspension was heat treated at $50^{\circ} \mathrm{C}$ for $30 \mathrm{~min}$. Another $10 \mathrm{ml}$ of the suspension was concentrated further by centrifugation at $4,000 \mathrm{rpm}$ for $30 \mathrm{~min}$, and $9 \mathrm{ml}$ of the supernatant was removed and discarded; the remaining $1 \mathrm{ml}$ was acidified with $9 \mathrm{ml}$ of $\mathrm{KCl}-\mathrm{HCl}$ buffer to $\mathrm{pH} 2.2$ (4) and allowed to stand for $5 \mathrm{~min}$. Portions $(0.1 \mathrm{ml})$ of the original and heat- and acid-treated suspensions were spread over the surfaces of three separate BCYE agar plates supplemented with glycine ( $3 \mathrm{~g} /$ liter), polymyxin B sulfate (79,200 IU/liter), vancomycin (5 mg/ liter), and cycloheximide ( $80 \mathrm{mg} / \mathrm{liter}$ ).

The plates were incubated at $35^{\circ} \mathrm{C}$ in the presence of high relative humidity for 7 days. At 2 -day intervals, the plates were examined with a stereoscopic dissecting microscope for colonies that had the ground-glass appearance that is typical of legionellae. A selection of such colonies was subcultured onto BCYE agar and nutrient agar plates. Isolates which grew on BCYE agar but not on nutrient agar 
after $48 \mathrm{~h}$ of incubation at $35^{\circ} \mathrm{C}$ were presumptively identified as Legionella species.

The serologic reactivity of the Legionella-like organisms was tested by using the indirect immunofluorescence technique. Rabbit antisera against Legionella species were obtained from the Division of Microbiological Reagents and Quality Control, Central Public Health Laboratory, Colindale, London, United Kingdom, and the sheep conjugate was obtained from the Wellcome Foundation, London, United Kingdom.

Monovalent antisera against $L$. pneumophila serogroups 1 through $13, L$. feeleii serogroups 1 and $2, L$. hackeliae serogroups 1 and $2, L$. israelensis, $L$. jordanis, $L$. jamestowniensis, $L$. longbeachae serogroups 1 and $2, L$. micdadei, L. oakridgensis, $L$. sainthelensi, $L$. santicrucis, $L$. gormanii, L. rubrilucens, and L. steigerwaltii were tested with the presumptive Legionella isolates by using whole cells as the antigen.

A representative isolate (strain $214^{\mathrm{T}}$ ), which did not react with the antisera listed above, was sent to the Public Health Laboratory Service facilities at Oxford and Porton Down, United Kingdom, and subsequently to the Centers for Disease Control, Atlanta, Ga., for further study.

Growth and biochemical tests. Strain $214^{\mathrm{T}}$ was grown on BCYE agar for all of the tests except the tests for autofluorescence and L-cysteine requirement. The buffer was omitted from the medium when autofluorescence was determined, and L-cysteine was omitted when the L-cysteine requirement was determined (26). The biochemical test methods which we used have been described previously (7).

Slide agglutination test. Strain $214^{\mathrm{T}}$ was tested with antisera against all previously characterized Legionella species $(n=32)$ and serogroups $(n=51)(3,5,20)$. Antiserum to strain $214^{\mathrm{T}}$ was prepared and tested as previously described (21).

Cellular fatty acids and isoprenoid quinones. Strain $214^{\mathrm{T}}$ cells were harvested from BCYE agar plates after 48,72 , or $96 \mathrm{~h}$ of incubation at $35^{\circ} \mathrm{C}$. The growth from one plate was harvested with approximately $1 \mathrm{ml}$ of distilled water and placed in a screw-cap tube (13 by $100 \mathrm{~mm}$ ). The cellular lipids were saponified with $1 \mathrm{ml}$ of $15 \% \mathrm{NaOH}$ in $50 \%$ aqueous methanol, and the liberated fatty acids were converted to fatty acid methyl esters as described previously (14). Cells were also hydrolyzed by heating them at $80^{\circ} \mathrm{C}$ for $16 \mathrm{~h}$ with $2.5 \mathrm{ml}$ of a mixture containing methanol, toluene, and $\mathrm{H}_{2} \mathrm{SO}_{4}$ (30:15:1), and the resulting fatty acid methyl esters were extracted with $2 \mathrm{ml}$ of hexane, followed by $2 \mathrm{ml}$ of a 1:1 mixture of ether and hexane. The combined organic layers were concentrated to $0.6 \mathrm{ml}$ with $\mathrm{N}_{2}$ and washed with buffer (14). Fatty acid methyl ester samples were analyzed by capillary gas-liquid chromatography, and the identities of the acids were confirmed as described previously (14). The isoprenoid quinone content of strain $214^{\mathrm{T}}$ was determined as described previously (14).

DNA methods. The guanine-plus-cytosine content of strain $214^{\mathrm{T}}$ DNA was determined spectrophotometrically by using the method of Marmur and Doty (15). The methods which we used for isolation and purification of DNA have been described previously (6). DNAs from strain $214^{\mathrm{T}}$ and from the species indicated in Table 1 , footnote $a$, were labeled enzymatically in vitro as described previously (7). Levels of DNA relatedness were determined by using the free-solution hydroxyapatite method performed at $60^{\circ} \mathrm{C}(6)$. We tested all of the previously described Legionella species except $L$. anisa, $L$. rubrilucens, $L$. cherrii, $L$. steigerwaltii, and $L$. santicrucis (7); each of these five species is at least $50 \%$
TABLE 1. Levels of DNA relatedness between strain $214^{\mathrm{T}}$ and other legionellae

\begin{tabular}{cc}
\hline Strain $^{a}$ & $\begin{array}{c}\% \text { Relatedness at } \\
60^{\circ} \mathrm{C} \text { to DNA } \\
\text { from strain } 214^{\mathrm{T}}\end{array}$ \\
\hline
\end{tabular}

L. shakespearei $214^{\mathrm{T}}$

100

L. jordanis BL-540

L. pneumophila Philadelphia 1

L. moravica 316-36

L. fairfieldensis 1725-AUS-E

L. dumoffii NY-23

L. gormanii LS-13.

L. bozemanii WIGA

L. wadsworthii $81-716 \mathrm{~A}$

Larisiensis PF-209C-C2

L. micdadei TATLOCK

L. feeleii WO-44C-C3...................................

L. sainthelensi Mount Saint Helens 4 .

L. erythra SE-32A-C8 ...

L. tucsonensis 1087-AZ-H

L. gratiana Lyon 8420412 .

L. hackeliae Lansing 2 .

L. cincinnatiensis $72-\mathrm{OH}-\mathrm{H}$

L. oakridgensis Oak Ridge 10 .

L. maceachernii PX-1-G2-E2...

L. jamestowniensis JA-26-G1-E2.

L. spiritensis Mount Saint Helens 9.

L. israelensis Bercovier 4 ...

L. quinlivanii 1442-AUS-E.

L. adelaidensis 1762-AUS-E ....

L. birminghamensis 1407-AL-H

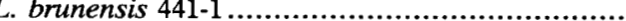

${ }^{a}$ In most experiments the labeled DNA which we used was strain $214^{T}$ DNA. The exceptions were the experiments in which we hybridized unlabeled strain $214^{\mathrm{T}}$ DNA with labeled DNAs from $L$. moravica $316-36, L$. fairfield ensis 1725-AUS-E, L. tucsonensis 1087-AZ-H, L. gratiana Lyon 8420412, L. cincinnatiensis $72-\mathrm{OH}-\mathrm{H}, L$. quinlivanii 1442-AUS-E, $L$. adelaidensis $1762-$ AUS-E, L. birminghamensis 1407-AL-H, and L. brunensis 441-1.

related to a species that was tested and that exhibited less than $10 \%$ relatedness to strain $214^{\mathrm{T}}$. Therefore, it was not necessary to test them directly against strain $214^{\mathrm{T}}$. Legionella species DNAs were obtained from the type strains in all cases.

\section{RESULTS}

A total of 17 Legionella-like colonies were isolated on the BCYE agar plate that was inoculated with the acid-treated concentrate obtained from the water sample (Houseman Ltd. laboratory reference no. 86030153); the only observable difference among these colonies was that some of the colonies which had the ground-glass appearance that is typical of legionellae were light pink across the whole colony. Young colonies that were visible only under the dissecting microscope were also pink, suggesting that production of the pigment was not an age-related process. The pink colonies did not react with any of the antisera used in indirect immunofluorescence assays. Nonpigmented colonies were not identified.

Growth characteristics and biochemical tests. Strain $214^{\mathrm{T}}$ was chosen for further study as a typical representative of the pink colonies. This organism required L-cysteine and iron for growth; autofluorescence was not observed when it was exposed to long-wavelength (365-nm) UV light. Microscopically, the cells were gram-negative bacilli with a single polar flagellum. Strain $214^{\mathrm{T}}$ was positive in tests for catalase, 
gelatinase, and $\beta$-lactamase and weakly positive in tests for oxidase. It was negative in tests for glucose fermentation, browning of tyrosine-supplemented agar, hippurate hydrolysis, nitrate reduction, and urease production.

Slide agglutination test. No agglutination was observed when strain $214^{\mathrm{T}}$ was tested with antisera to the 32 previously recognized species and 51 serogroups of the genus Legionella. Antiserum prepared against strain $214^{\mathrm{T}}$, at the optimal working dilution of $1: 8$, gave a $4+$ agglutination reaction with its homologous antigen (whole cells) and was negative with all other Legionella antigens.

Cellular fatty acids. Like other legionellae, strain $214^{\mathrm{T}}$ contained large amounts $(>50 \%)$ of branched-chain acids and only trace to small amounts of hydroxy acids. The major acids were 14-methylpentadecanoic acid $\left(\mathrm{C}_{\mathrm{i}-16: 0}\right)(29 \%)$, hexadecenoate $\left(C_{n-16: 1}\right)(16 \%)$, hexadecanoate $\left(C_{n-16: 0}\right)$ $(11 \%)$, 12-methyltetradecanoate $\left(\mathrm{C}_{\mathrm{a}-15: 0}\right)(10 \%)$, and 12-methyltridecanoate $\left(\mathrm{C}_{\mathrm{i}-14: 0}\right)(9 \%)$. Other acids detected were pentadecenoate $\left(C_{n-15: 1}\right)(5 \%)$, pentadecanoate $\left(C_{n-15: 0}\right)(4 \%)$, heptadecanoate $\left(\mathrm{C}_{\mathrm{n}-17: 0}\right) \quad(4 \%)$, 14-methylhexadecanoate $\left(\mathrm{C}_{\mathrm{a}-17: 0}\right)(3 \%)$, 13-methyltetradecanoate $\left(\mathrm{C}_{\mathrm{i}-15: 0}\right)(2 \%), 15$-methylhexadecanoate $\left(\mathrm{C}_{\mathrm{i}-17: 0}\right)(1 \%)$, octadecanoate $\left(\mathrm{C}_{\mathrm{n}-18: 0}\right)$ (1\%), and 3-hydroxy-12-methyltridecanoate ( $\left.\mathrm{C}_{\mathrm{i}-3-\mathrm{OH}-14: 0}\right)$ $(1 \%)$. Essentially identical profiles were obtained with five separate strain $214^{\mathrm{T}}$ cell preparations, as well as with cells processed after 48,72 , and $96 \mathrm{~h}$ of incubation. Acid-hydrolyzed cells yielded increased amounts of $\mathrm{C}_{\mathrm{i}-3-\mathrm{OH}-14: 0}$ and small amounts (1 to $2 \%)$ of three hydroxy acids $\left(\mathrm{C}_{3-\mathrm{OH}-16: 0}\right.$,

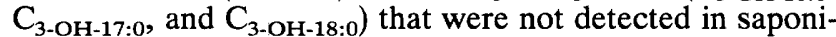
fied cells.

Isoprenoid quinones. Strain $214^{\mathrm{T}}$ contained ubiquinones with $10,11,12$, and 13 isoprene units $(\mathrm{Q}-10, \mathrm{Q}-11, \mathrm{Q}-12$, Q-13, respectively) in the polyprenoid side chain. Q-12 was the major ubiquinone and was present at a concentration which was approximately three times the concentrations of Q-10, Q-11, and Q-13.

DNA studies. The guanine-plus-cytosine content of DNA from strain $214^{\mathrm{T}}$ was $45.5 \mathrm{~mol} \%$. DNA from strain $214^{\mathrm{T}}$ was $25 \%$ related to DNA from $L$. jordanis and less than $10 \%$ related to DNAs from other Legionella species.

\section{DISCUSSION}

Strain $214^{\mathbf{T}}$ was identified as a member of the genus Legionella on the basis of its cultural and biochemical characteristics, its cellular fatty acid composition, and its isoprenoid quinone content. Strain $214^{\mathrm{T}}$ did not react with antiserum to any of the 51 previously described serogroups of Legionella species. This meant that strain $214^{\mathrm{T}}$ was a member of either a new species or a new serogroup of an existing species. We confirmed that this organism was a member of a new species on the basis of its levels of DNA relatedness to previously described species (25\% or less).

The species represented by strain $214^{\mathrm{T}}$ can be identified serologically, by a combination of its cellular fatty acids and isoprenoid quinone content, and by DNA hybridization. The production of the pink pigment by this new species, which persisted when the organism was subcultured, should aid in its identification.

The presence of $\mathrm{C}_{\mathrm{i}-16: 0}$ as the major cell wall acid distinguishes strain $214^{\mathrm{T}}$ from all other legionellae except $L$. pneumophila, $L$. oakridgensis, and $L$. spiritensis (14). Strain $214^{\mathrm{T}}$ contains smaller amounts of $\mathrm{C}_{\mathrm{n}-18: 0}$ and larger amounts of $\mathrm{C}_{\mathrm{i}-14: 0}$ and $\mathrm{C}_{\mathrm{a}-15: 0}$ than $L$. oakridgensis. It differs from $L$. pneumophila and $L$. spiritensis by the presence of $\mathrm{C}_{\mathrm{i}-15: 0}$ and the absence of a branched-chain monounsaturated 16-carbon acid $\left(C_{i-16: 1 B}\right)$ and a 17-carbon cyclopropane acid $\left(C_{n-17: 0 c y c}\right)$.

Other than strain $214^{\mathrm{T}}$, only $L$. pneumophila, L. erythra, and $L$. rubrilucens contain Q-12 as the major quinone. These species are differentiated from strain $214^{\mathrm{T}}$ by the absence (or presence of only trace amounts) of Q-10 (14).

We propose the name Legionella shakespearei for the Legionella species represented by strain $214^{\mathrm{T}}$. The species description is given below.

Description of Legionella shakespearei sp. nov. Legionella shakespearei (shakes.pear. $\mathrm{e}^{\prime}$ i. N. L. gen. n. shakespearei, named after the playwright William Shakespeare because the organism was isolated in Stratford-upon-Avon) is a weakly oxidase-positive, catalase-positive, $\beta$-lactamase-positive, gelatinase-positive, gram-negative bacillus that has a single polar flagellum and does not autofluoresce. Colonies grown on BCYE agar are light pink across the entire colony and have a ground-glass appearance. The organism requires L-cysteine and does not ferment glucose, brown tyrosinesupplemented agar, hydrolyze hippurate, reduce nitrate, or produce urease. $\mathrm{C}_{\mathrm{i}-16: 0}$ is the predominant cell wall fatty acid; other major fatty acids are $C_{n-16: 1}, C_{n-16: 0}, C_{a-15: 0}$, and $\mathrm{C}_{\mathrm{i}-14: 0}$. The predominant quinone has 12 isoprene units in the polyprenoid side chain; other major quinones have 10,11 , or 13 side units. The type strain is strain 214 (= ATCC 49655), which has a guanine-plus-cytosine content of $45.5 \mathrm{~mol} \%$.

\section{REFERENCES}

1. Band, J. D., M. LaVenture, J. P. Davis, G. F. Mallison, P. Skaliy, P. S. Hayes, W. L. Schell, H. Weiss, D. J. Greenberg, and D. W. Fraser. 1981. Epidemic Legionnaires' disease: airborne transmission down a chimney. J. Am. Med. Assoc. 245:2404 2407.

2. Baskerville, A., R. B. Fitzgeorge, M. Broster, P. Hambleton, and P. J. Dennis. 1981. Experimental transmission of Legionnaires' disease by exposure to aerosols of Legionella pneumophila. Lancet ii:1389-1390.

3. Benson, R. F., W. L. Thacker, J. A. Lanser, N. Sangster, W. R. Mayberry, and D. J. Brenner. 1991. Legionella adelaidensis, a new species isolated from cooling tower water. J. Clin. Microbiol. 29:1004-1006.

4. Bopp, C. A., J. W. Sumner, G. K. Morris, and J. G. Wells. 1981. Isolation of Legionella spp. from environmental water samples by low-pH treatment and use of a selective medium. J. Clin. Microbiol. 13:714-719.

5. Bornstein, N., D. Marmet, M. Surgot, M. Nowicki, H. Meugnier, J. Fleurette, E. Ageron, F. Grimont, P. A. D. Grimont, W. L. Thacker, R. F. Benson, and D. J. Brenner. 1989. Legionella gratiana sp. nov. isolated from French spa water. Res. Microbiol. 140:541-552.

6. Brenner, D. J., A. C. McWhorter, J. K. Leete Knutson, and A. G. Steigerwalt. 1982. Escherichia vulneris: a new species of Enterobacteriaceae associated with human wounds. J. Clin. Microbiol. 15:1133-1140.

7. Brenner, D. J., A. G. Steigerwalt, G. W. Gorman, H. W. Wilkinson, W. F. Bibb, M. Hackel, R. L. Tyndall, J. Campbell, J. C. Feeley, W. L. Thacker, P. Skaliy, W. T. Martin, B. J. Brake, B. S. Fields, H. V. McEachern, and L. K. Corcoran. 1985. Ten new species of Legionella. Int. J. Syst. Bacteriol. 35:50-59.

8. Colbourne, J. S., and P. J. L. Dennis. 1988. Legionella: a biofilm organism in engineered water systems?, p. 36-42. In D. R. Houghton et al. (ed.), Biodeterioration 7: 7th International Biodeterioration Symposium. Elsevier Applied Science, Barking, United Kingdom.

9. Dennis, P. J. L., A. E. Wright, D. A. Rutter, J. E. Death, and B. P. C. Jones. 1984. Legionella pneumophila in aerosols from shower baths. J. Hyg. 93:349-353.

10. Dondero, T. J., R. C. Rendtorfi, G. F. Mallison, R. M. Weeks, J. S. Levy, E. W. Wong, and W. Schaffner. 1980. An outbreak of 
Legionnaires' disease associated with a contaminated air-conditioning cooling tower. New Engl. J. Med. 302:365-370.

11. Dutka, B. J., and K. Walsh. 1984. Incidence of Legionella organisms in selected Ontario (Canada) cities. Sci. Total Environ. 39:237-249.

12. Fliermans, C. B., W. B. Cherry, L. H. Orrison, S. J. Smith, D. L. Tison, and D. H. Pope. 1981. Ecological distribution of Legionella pneumophila. Appl. Environ. Microbiol. 41:9-16.

13. Kurtz, J. B., C. L. R. Bartlett, U. A. Newton, R. A. White, and N. L. Jones. 1982. Legionella pneumophila in cooling water systems. J. Hyg. 88:369-381.

14. Lambert-Fair, M. A., and C. W. Moss. 1989. Cellular fatty acid composition and isoprenoid quinone contents of 23 Legionella species. J. Clin. Microbiol. 27:465-473.

15. Marmur, J., and P. Doty. 1962. Determination of the base composition of deoxyribonucleic acid from its thermal denaturation temperature. J. Mol. Biol. 5:109-118.

16. Mauchline, W. S., and C. W. Keevil. 1991. Development of the BIOLOG substrate utilization system for identification of Legionella spp. Appl. Environ. Microbiol. 57:3345-3349.

17. Meenhorst, P. L., A. L. Reingold, G. W. Gorman, J. C. Feeley, B. J. van Cronenburg, C. L. M. Meyer, and R. van Furth. 1983. Legionella pneumonia in guinea pigs exposed to aerosols of concentrated potable water from a hospital with nosocomial Legionnaires' disease. J. Infect. Dis. 147:129-132.

18. Morris, G. K., C. M. Patton, J. C. Feeley, S. E. Johnson, G. Gorman, W. T. Martin, P. Skaliy, G. F. Mallison, B. D. Politi, and D. C. Mackel. 1979. Isolation of the Legionnaires' disease bacterium from environmental samples. Ann. Intern. Med. 90:664-666.

19. Saunders, N. A., N. Doshi, and T. G. Harrison. 1992. A second serogroup of Legionella erythra serologically indistinguishable from Legionella rubrilucens. J. Appl. Bacteriol. 72:262-265.

20. Thacker, W. L., R. F. Benson, L. Hawes, H. Gidding, B. Dwyer, W. R. Mayberry, and D. J. Brenner. 1991. Legionella fairfieldensis sp. nov. isolated from cooling tower waters in Australia. J. Clin. Microbiol. 29:475-478.

21. Thacker, W. L., B. B. Plikaytis, and H. W. Wilkinson. 1985. Identification of 22 Legionella species and 33 serogroups with the slide agglutination test. J. Clin. Microbiol. 21:779-782.

22. Tison, D. L., D. H. Pope, W. B. Cherry, and C. B. Fliermans. 1980. Growth of Legionella pneumophila in association with blue-green algae (cyanobacteria). Appl. Environ. Microbiol. 39:456-459.

23. Tobin, R. S., P. Ewan, K. Walsh, and B. Dutka. 1986. A survey of Legionella pneumophila in water in 12 Canadian cities. Water Res. 20:495-501.

24. Tyndall, R. L., and E. L. Domingue. 1982. Co-cultivation of Legionella pneumophila and free-living amoebae. Appl. Environ. Microbiol. 44:954-959.

25. Wadowsky, E. M., and R. B. Yee. 1981. Effect of non-Legionellaceae bacteria on the multiplication of Legionella pneumophila in potable water. Appl. Environ. Microbiol. 42:768-772.

26. Wilkinson, H. W. 1987 . Hospital-laboratory diagnosis of Legionella infections, 2nd printing, January 1988 (revised). Centers for Disease Control, Atlanta. 